\title{
Article \\ Spatial Succession for Degradation of Solid Multicomponent Food Waste and Purification of Toxic Leachate with the Obtaining of Biohydrogen and Biomethane
}

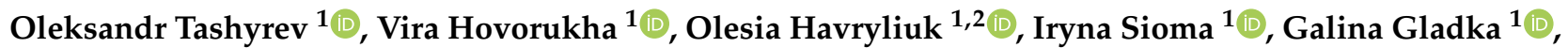 \\ Olga Kalinichenko $^{3, *(\mathbb{D})}$, Paweł Włodarczyk ${ }^{3}(\mathbb{D})$, Dariusz Suszanowicz ${ }^{3} \mathbb{D}$, Hennadiy Zhuk ${ }^{4}(\mathbb{D})$ and Yuri Ivanov ${ }^{4}$
}

1 Department of Extremophilic Microorganisms Biology, Zabolotny Institute of Microbiology and Virology of the National Academy of Sciences of Ukraine, 03143 Kyiv, Ukraine; tach2007@ukr.net (O.T.); vira-govorukha@ukr.net (V.H.); gav_olesya@ukr.net (O.H.); irasioma82@gmail.com (I.S.); gladkagv@ukr.net (G.G.)

2 Department of Biotechnology, Faculty of Environmental Safety, Engineering and Technologies, National Aviation University, 03058 Kyiv, Ukraine

3 Institute of Environmental Engineering and Biotechnology, University of Opole, 45-040 Opole, Poland; pawel.wlodarczyk@uni.opole.pl (P.W.); dareks@uni.opole.pl (D.S.)

4 Gas Technologies Department, Gas Institute of the National Academy of Sciences of Ukraine, 03113 Kyiv, Ukraine; hen_zhuk@ukr.net (H.Z.); ivjuv2102@ukr.net (Y.I.)

* Correspondence: 123507@student.uni.opole.pl; Tel.: +48-787-321-587

check for updates

Citation: Tashyrev, O.; Hovorukha, V.; Havryliuk, O.; Sioma, I.; Gladka,

G.; Kalinichenko, O.; Włodarczyk, P.; Suszanowicz, D.; Zhuk, H.; Ivanov, Y. Spatial Succession for Degradation of Solid Multicomponent Food Waste and Purification of Toxic Leachate with the Obtaining of Biohydrogen and Biomethane. Energies 2022, 15, 911. https://doi.org/10.3390/ en15030911

Academic Editor: Vimal

Viswanathan

Received: 15 December 2021

Accepted: 25 January 2022

Published: 27 January 2022

Publisher's Note: MDPI stays neutral with regard to jurisdictional claims in published maps and institutional affiliations.

Copyright: (c) 2022 by the authors. Licensee MDPI, Basel, Switzerland. This article is an open access article distributed under the terms and conditions of the Creative Commons Attribution (CC BY) license (https:/ / creativecommons.org/licenses/by/ $4.0 /)$.

\begin{abstract}
A huge amount of organic waste is generated annually around the globe. The main sources of solid and liquid organic waste are municipalities and canning and food industries. Most of it is disposed of in an environmentally unfriendly way since none of the modern recycling technologies can cope with such immense volumes of waste. Microbiological and biotechnological approaches are extremely promising for solving this environmental problem. Moreover, organic waste can serve as the substrate to obtain alternative energy, such as biohydrogen $\left(\mathrm{H}_{2}\right)$ and biomethane $\left(\mathrm{CH}_{4}\right)$. This work aimed to design and test new technology for the degradation of food waste, coupled with biohydrogen and biomethane production, as well as liquid organic leachate purification. The effective treatment of waste was achieved due to the application of the specific granular microbial preparation. Microbiological and physicochemical methods were used to measure the fermentation parameters. As a result, a four-module direct flow installation efficiently couples spatial succession of anaerobic and aerobic bacteria with other micro- and macroorganisms to simultaneously recycle organic waste, remediate the resulting leachate, and generate biogas.
\end{abstract}

Keywords: spatial succession; environmental contamination; food waste; recycling; dark fermentation; methanogenesis; syntrophy

\section{Introduction}

Our world generates annually over 2.01 billion tons of solid and liquid organic waste from municipalities and canning and food industries [1-5]. Most of it is disposed of in environmentally unfriendly way since none of the modern recycling technologies can cope with such immense volumes of waste. This situation has resulted in a steady rise in the number and volume of landfills around the globe [6-8]. The spontaneous decay of buried organic waste occurs slowly and is accompanied by decade-long emissions of hazardous gaseous products into the environment: hydrogen sulfide $\left(\mathrm{H}_{2} \mathrm{~S}\right)$, ammonia $\left(\mathrm{NH}_{3}\right)$, methane $\left(\mathrm{CH}_{4}\right)$, carbon dioxide $\left(\mathrm{CO}_{2}\right)$, and mercaptans [9-11]. The landfills also produce toxic leachate containing very high levels of fatty acids and alcohols generated by the hydrolysis of plant and animal polymer compounds [11,12]. For example, the concentration of acetic acid in the leachate of the Taichung City landfill (Taiwan) was $2372 \pm 95 \mathrm{mg} / \mathrm{L}$ [13]. The analysis of landfill leachate collected near Abidjan, Côte d'Ivoire, 
revealed fatty acids levels ranging between 1646 and 22,000 mg/L and $959.65 \mathrm{mg} / \mathrm{L}$ for $\mathrm{C}_{6}-\mathrm{C}_{8}$ and $\mathrm{C}_{9}-\mathrm{C}_{10}$ compounds [14]. These highly concentrated volatile fatty acids inhibit the growth of methanogens and primary anaerobes (Clostridium spp.), which slows the waste decay and pollutes the environment [15-17].

The reduction in fossil fuels and greenhouse gas emissions is a vital priority for the sustainable development of society and the modern economy $[18,19]$. Among alternative approaches for dealing with organic waste is its recycling using microbial technologies to simultaneously produce gaseous energy carriers, such as hydrogen and methane. Molecular hydrogen is a promising environmentally safe, high-energy, and cost-effective alternative to fossil fuels that can be generated via dark fermentation $[19,20]$. However, the practical implementation of this technology remains challenging. Much attention has been focused on studying biochemical pathways for hydrogen synthesis. Still, there is a lack of detailed information on biohydrogen production from short-chain fatty acids and alcohols obtained via fermentation of organic waste [17-19]. An alternative approach to converting organic waste into green energy involves recycling in biogas plants for the simultaneous production of biohydrogen or biomethane. These attempts also did not succeed and were hampered by a slow and inefficient (in terms of the decrease in mass and volume) fermentation process [21]. The waste processing in biogas plants generates liquid and solid digestate, which commercial enterprises often market as a high-quality, environmentally friendly commodity that increases soil fertility and crop yield [22,23]. However, we found that the soil treatment with leachate from fermented food waste resulted in poor germination of radish seeds [24].

It is clear that the key to the efficient recycling of mixed organic substrates and byproducts of this process lies in the optimization of fermentation processes. Therefore, this work aimed to design and test new technology for the degradation of food waste coupled with hydrogen and methane production. This approach overcomes many existing challenges by employing a balanced artificial syntrophic food chain that includes anaerobic hydrogen-producing bacteria and methanogens, aerobic bacteria, Protozoa, microscopic invertebrates, insect larvae, and fish. The key components of this system are primary anaerobes that hydrolyze organic polymers, synthesize biohydrogen, and secrete exometabolites ultimately consumed by a biomethane-producing microbial community. The efficient function is ensured by priming the system with granular microbial inocula and housing individual syntrophic communities in separate connected modules.

\section{Materials and Methods}

\subsection{Multifunctional Wastewater Flow Installation for the Removal of Organic Compounds and Biogas Synthesis}

We designed a modular flow installation that treats multicomponent solid food waste and associated leachate by converting soluble organic compounds into non-toxic, ecologically friendly metabolites. The system consisted of four modules connected in series (Figure 1). The first module (hydrogen bioreactor) degraded solid organic waste and synthesized biohydrogen (Figure 1a). The second module (methane tank) was employed to convert the end products of the hydrogen fermentation (fatty acids and alcohols) into methane (Figure 1b). Next, aerobic microorganisms in the third module (air tank) consumed residual organic compounds and methanogen biomass. The bacteria growing in water were removed by protozoa, which, in turn, were consumed by Rotifera spp. and nematodes. The protozoa also served as a nutrient source for insect larvae (Figure 1c), which the fish ultimately consumed in the aquarium (Figure 1d). 


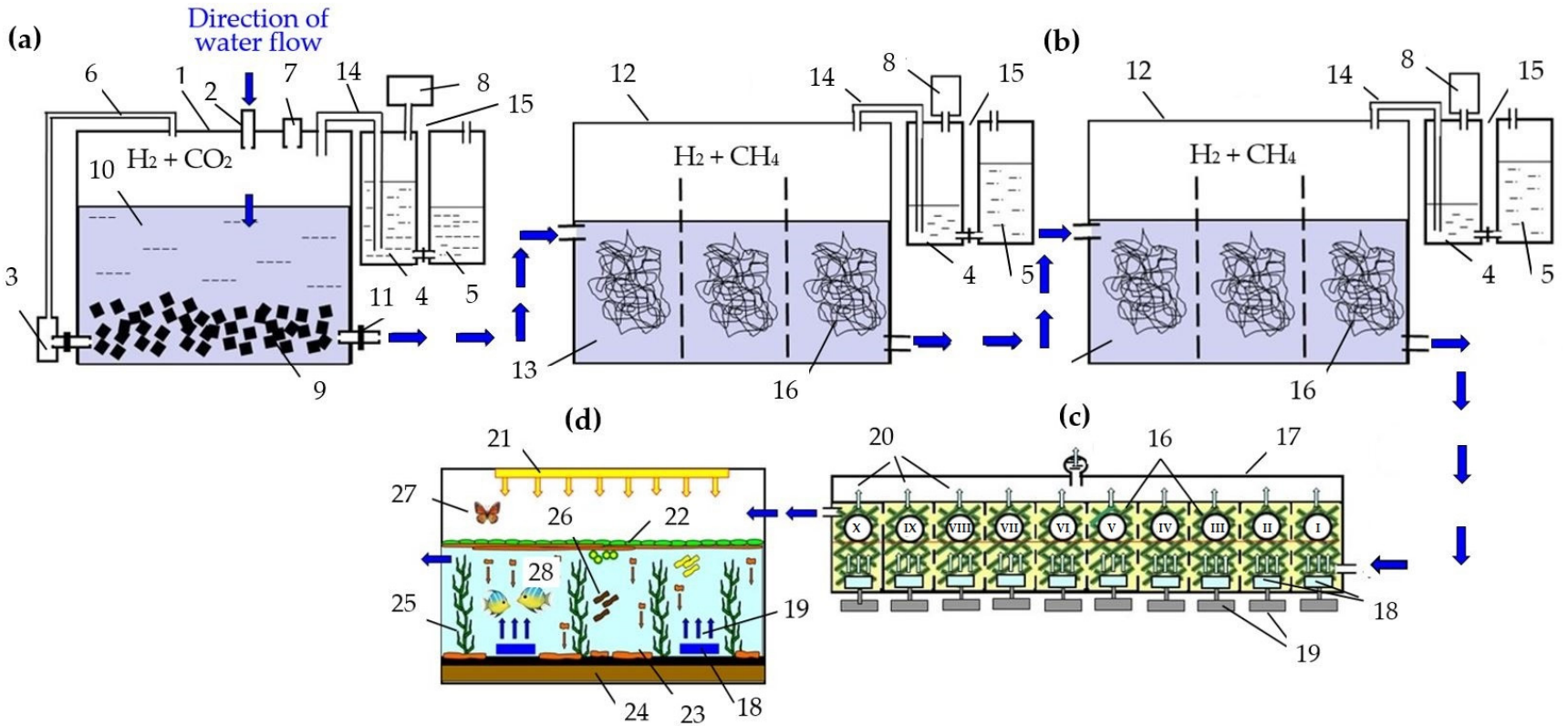

Figure 1. Scheme of the multifunctional direct flow installation for degradation of solid and liquid organic waste: (a) hydrogen bioreactor $(240 \mathrm{~L})$; (b) methane tank (two connected modules, $50 \mathrm{~L}$ each); (c) air tank (50 L); (d) aquarium (50 L): 1-steel body; 2-water supply fitting; 3-pump; 4-gas holder; 5-hydro lock; 6-mass transfer pipe; 7-hatch for the loading of solid food waste; 8-installation for the purification of biohydrogen; 9-solid food waste; 10 -leachate (liquid phase); 11-lock for the leachate transfer to methane tank; 12 - transparent plastic housing of methane tank; 13-hydrogen fermentation leachate; 14-biogas removal tube; 15-gasholder system; 16-inert carriers for the microbial attachment and biofilm development; 17-transparent plastic housing (I ... X- numbers of sections); 18-aerators; 19-air supply compressors for the aerobic module; 20-air sprays inside the culture fluid; 21-light source; 22-biofilm of Lemna sp. and microalgae; 23-microalgal detritus; 24-soil; 25-stream algae; 26-Protozoa; 27-insects; 28-fish.

Before starting water flow, the modular flow installation was prepared as follows. The hydrogen bioreactor was loaded with food waste and the granular microbial preparation GMP1, which contains hydrogen synthesizing microbial community. Next, the methane tank was inoculated with the methanogenic microbial preparation GMP2. The properties of the hydrogen (GMP1) and methanogenic (GMP2) preparations are described in our previous studies $[25,26]$. The modification of the GMP1 was added into the hydrogen bioreactor and the GMP2 into methane tank to increase the efficiency of the fermentation. The multi-section $0.31 \times 0.31 \times 0.5 \mathrm{~m}$ plexiglass air tank was loaded with inert synthetic (nylon wire) and natural (hay, straw) carriers containing immobilized aerobic microorganisms, protozoan cysts, and insect eggs. The aquarium module received duckweed, microalgae, stream algae, Protozoa, insect larvae, and fish. The first three modules were hermetically sealed, while the fourth (aquarium) remained opened, and all four vessels were connected with tubing. Such a flow-through system provided the spatial succession of ecobiomes within the installation.

The hydrogen bioreactor performed the hydrolysis of solid food waste accompanied by the synthesis of gases $\left(\mathrm{H}_{2}, \mathrm{CO}_{2}\right)$ and soluble organic compounds (fatty acids, alcohols). This module was loaded with a total of $20 \mathrm{~kg}$ of solid food waste, consisting of partially rotten potatoes $(5 \mathrm{~kg})$, apples $(4 \mathrm{~kg})$, spoiled potato peelings $(3 \mathrm{~kg})$, overdue pasta $(2 \mathrm{~kg})$, moldy black and white bread $(3 \mathrm{~kg})$, sour rice $(1 \mathrm{~kg})$, and banana peels $(2 \mathrm{~kg})$. These ingredients were chopped into $1.0-2.0-\mathrm{cm}^{3}$ pieces. The ratio of solid (waste) to liquid (water) phases was 1:8. Before starting the flow, the bioreactor was inoculated with GMP1 and left for $12 \mathrm{~h}$ to activate the growth of hydrogen-synthesizing microorganisms. After that, the water was fed through the fitting 2 (Figure 1a) at a flow rate of $0.5 \mathrm{~L} / \mathrm{h}$, which effectively initiated the direct flow through the entire installation. 
The hydrogen bioreactor leachate containing high levels of organic compounds was transported into the anaerobic module, consisting of two methane tanks, holding $40 \mathrm{~L}$ of liquid each (Figure 2). The methane tanks were equipped with gasholders that accumulated and stored the synthesized gas by displacing the corresponding volume of water. The gas sampling was performed by piercing the rubber hoses of the gasholder with a syringe and needle. Each methane tank was also equipped with evenly spaced ports for sampling the culture fluid, which was performed by piercing the rubber stopper with a sterile syringe with a needle. The samples of culture fluid were used to perform microscopic observations of the microbial communities and monitor levels of Eh, $\mathrm{pH}$, optical density (microbial biomass concentration), and soluble organic compounds.

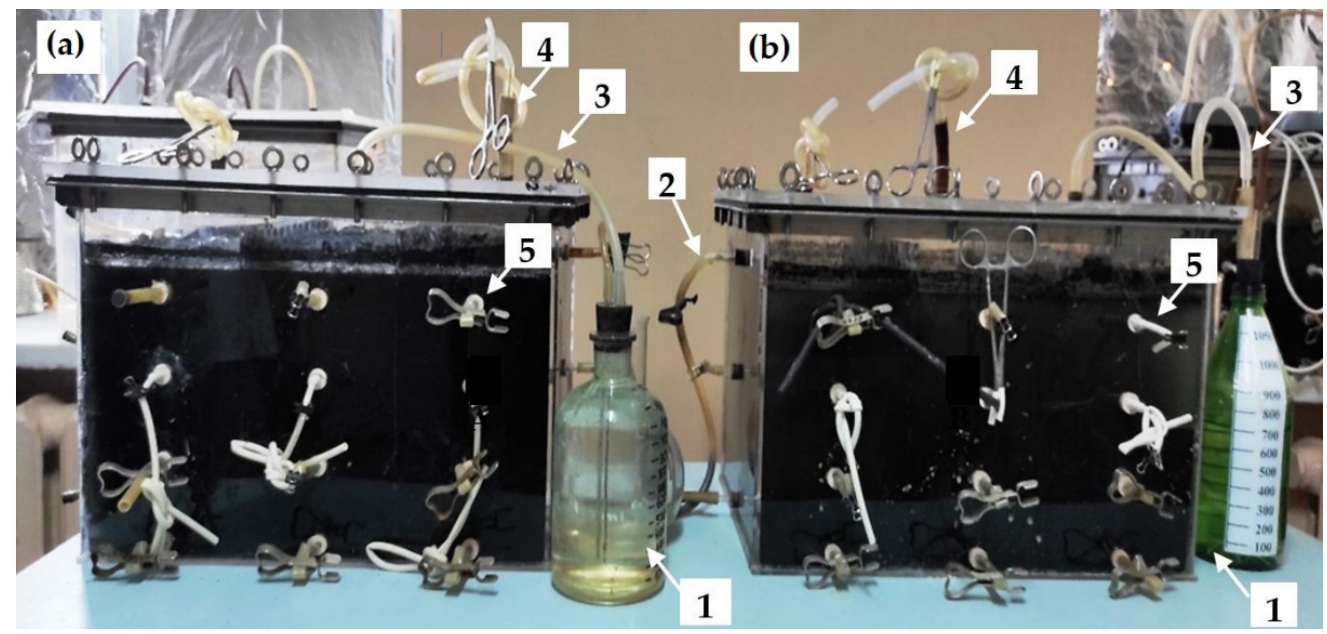

Figure 2. Methane tank for the methanogenic fermentation of organic acids and alcohols. The phot shows two connected 50-L modules 1 and 2 for the fermentation of high concentrations (1000-2000 mg/L) of organic compounds (a),(b). The system included gas holders (1), a tube connecting the two modules (2), gas collecting tubes (3), gas sampling tubes (4), and leachate sampling ports (5).

The methane tank leachate was streamed into a 50-L air tank with aerobic microorganisms (Figure 1c). This module was subdivided into ten sections separated with partitions perforated with 3-mm diameter holes. The aeration was performed by forcing compressed air into each section. The air exhaust pipe had a filter to prevent the ejection of microbial aerosols. The methane tank leachate containing the alcohols, fatty acids, and residual anaerobe biomass passed through the air tank, where the oxidation of organic compounds took place. The aerobic microorganisms served as a nutrient source for Protozoa, which fed rotifers, nematodes, and insect larvae. After passing through the air tank, the purified water was transferred into the last module to remove rotifers, nematodes, and insect larvae (Figure 1d). This module was a plastic aquarium filled with water, sediment, flora, and fauna from a natural pond. The ecobiome contained autotrophic and heterotrophic microorganisms, microalgae, duckweed (Lemna sp.), stream algae, insect larvae, and crucian carp (Carassius carassius). The system was wholly self-sufficient and did not require additional carbon sources.

The overall scheme of the experimental setup is summarized in Figure 3. The installation consisted of four modules connected in series and performing the following biological processes:

1. Module 1 (hydrogen bioreactor): the degradation (hydrolysis) of multicomponent solid food waste by anaerobic microorganisms accompanied by the synthesis of $\mathrm{H}_{2}$, $\mathrm{CO}_{2}$, VFA, and alcohols.

2. Module 2 (methane tank): the methanogenic degradation of VFA and alcohols, the end products of the hydrogen fermentation. 
3. Module 3 (air tank): The anaerobe biomass removal by the following food chain: “aerobic microorganisms $\rightarrow$ Protozoa $\rightarrow$ invertebrates (nematodes, Rotifera) $\rightarrow$ insect larvae."

4. Module 4 (aquarium): the removal of rotifers, nematodes, and insect larvae by fish.

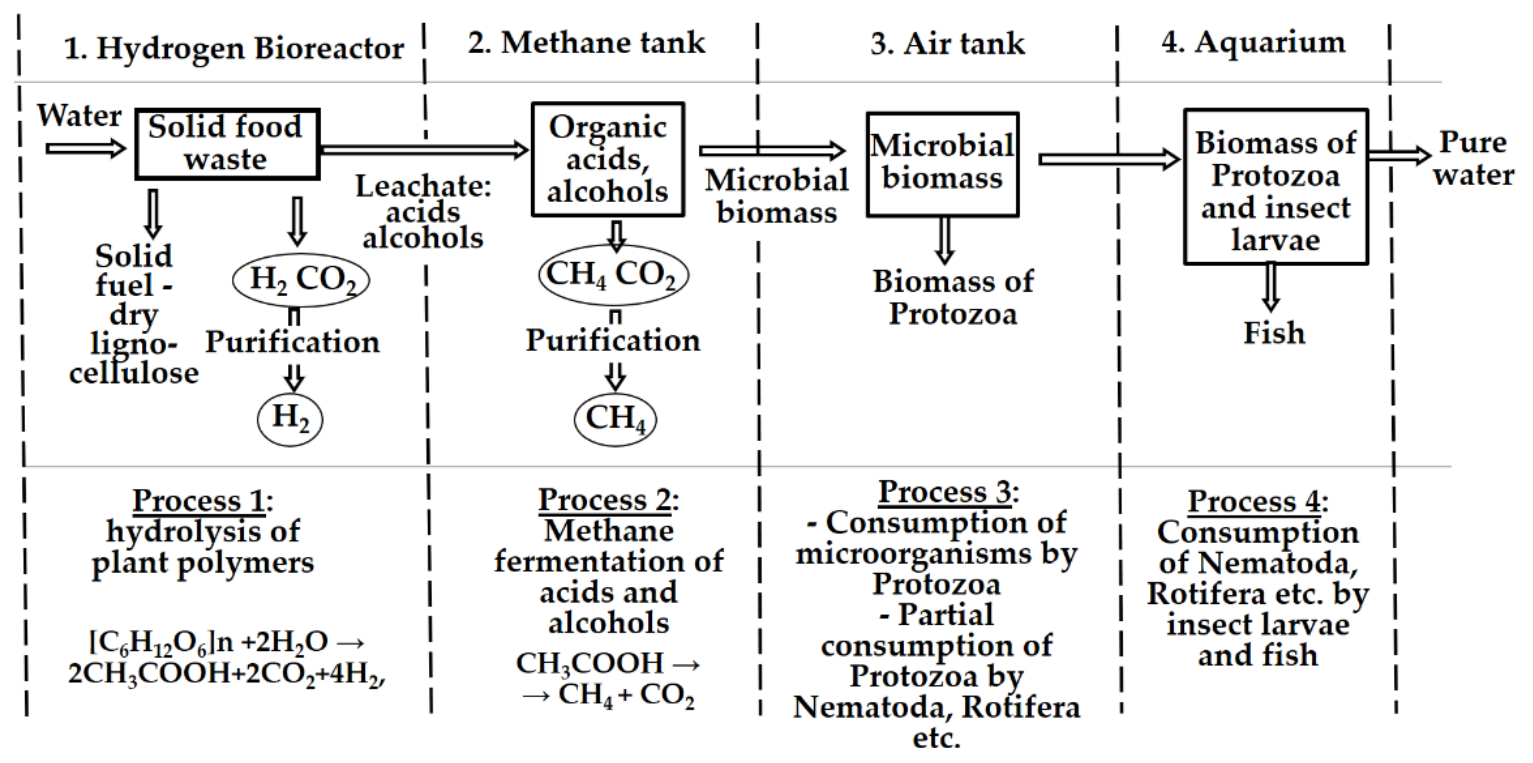

Figure 3. The summary of biological processes in the modular flow installation used in this study.

The spatial succession of the four ecobiomes in a modular flow installation provided the simultaneous degradation of solid food waste, the leachate's purification, the microbial biomass's removal, and the generation of energy sources in the form of biohydrogen and methane.

\subsection{Carriers for the Immobilization of Microorganisms}

A combination of inert synthetic and natural carriers was used to immobilize microorganisms in the methane and air tanks (Table 1). The natural carriers were left non-sterile to preserve the aboriginal microflora, Protozoa, and insect larvae. The methane tank was filled with nylon fibers and inoculated with the microbial preparation GMP2, which contains a methanogen community. The aerobic biofilms were grown in air tank sections containing a combination of synthetic and natural carriers. Each section was inoculated with $5 \mathrm{~g}$ of solids from activated sludge collected at the Bortnychi sewage treatment plant (Kyiv, Ukraine). The microorganisms were allowed to immobilize on the carrier material for a total of $12 \mathrm{~h}$.

\subsection{Collection of Biohydrogen and Biomethane}

The gases synthesized in the hydrogen bioreactor and methane tanks first accumulated in gasholders (Figure 1a,b) and then entered biogas purification units (Figure 1a7,b). The biohydrogen and biomethane were purified by trapping carbon dioxide and other impurities (ammonia, hydrogen sulfide) in aqueous solutions of methyldiethanolamine and monoethanolamine [27]. The content of methyldiethanolamine and monoethanolamine was $40 \%$ and $10 \%$, respectively.

\subsection{Control of Metabolic Parameters during the Wastewater Treatment}

The efficiency of biohydrogen and biomethane synthesis during the degradation of food waste and leachate purification was monitored by assessing the duration of the fermentation cycle $(T, h)$, degree of waste degradation $(K d$, the ratio of the initial and end mass), maximum concentration and volume of gas mixtures and their content $\left(\mathrm{H}_{2}, \mathrm{O}_{2}, \mathrm{~N}_{2}\right.$, $\left.\mathrm{CH}_{4}, \mathrm{CO}_{2}\right)$, biohydrogen yield $\left(\mathrm{VH}_{2}, \mathrm{~L} / \mathrm{kg}\right.$ of solid waste), biomethane yield $\left(\mathrm{CH}_{4}, \mathrm{~L} / \mathrm{L}\right.$ of 
leachate), $\mathrm{pH}$, Eh, levels of soluble organic compounds in the filtrate, and production of the microbial biomass [25].

Table 1. Carrier materials used to immobilize microorganisms.

\begin{tabular}{|c|c|c|c|}
\hline$\#$ & Carrier & Type & Main Features \\
\hline 1 & Basalt wool & Synthetic & $\begin{array}{l}\text { Highly branched structure and excellent resistance to } \\
\text { microbial degradation. Supports thin surface microbial } \\
\text { biofilms. Can be re-used repeatedly after calcination } \\
\text { (sterilization) without loss of basic properties. }\end{array}$ \\
\hline 2 & Basalt fiber & $\begin{array}{l}\text { Synthetic } \\
\text { mineral }\end{array}$ & $\begin{array}{l}\text { Excellent resistance to microbial degradation, but smaller } \\
\text { fouling surface compared to basalt wool. Can be reused by } \\
\text { simple cleaning and washing. }\end{array}$ \\
\hline 3 & Household packaging net & $\begin{array}{l}\text { Synthetic } \\
\text { mineral }\end{array}$ & $\begin{array}{l}\text { Moderately branched structure and good resistance to } \\
\text { microbial degradation. Maintains structure even during } \\
\text { heavy microbial fouling. Good washability. }\end{array}$ \\
\hline 4 & Nylon fiber & $\begin{array}{l}\text { Synthetic } \\
\text { organic }\end{array}$ & $\begin{array}{l}\text { Widely used as a carrier for bioremediation purposes. } \\
\text { Resistant to microbial degradation. Good washability. } \\
\text { Maintains structure even during heavy microbial fouling. }\end{array}$ \\
\hline 5 & Polyethylene foam & $\begin{array}{l}\text { Synthetic } \\
\text { organic }\end{array}$ & $\begin{array}{l}\text { Resistant to microbial degradation. During fouling, supports } \\
\text { formation of thick microbial biofilms. }\end{array}$ \\
\hline 6 & Hay & $\begin{array}{l}\text { Natural } \\
\text { organic }\end{array}$ & $\begin{array}{c}\text { Contains indigenous microflora. Provides nutrients for } \\
\text { microbial growth and promote the development of different } \\
\text { Protozoa (flagellates, ciliates, amoebae) and microscopic } \\
\text { invertebrates (nematodes). }\end{array}$ \\
\hline 7 & Straw & $\begin{array}{l}\text { Natural } \\
\text { organic }\end{array}$ & $\begin{array}{l}\text { Provides nutrients for microbial growth. Larger fouling } \\
\text { surface compared to hay. The inner stem surface promotes } \\
\text { growth of microaerophilic microorganisms. }\end{array}$ \\
\hline 8 & Dried marigold stalks & $\begin{array}{l}\text { Natural } \\
\text { organic }\end{array}$ & $\begin{array}{l}\text { Provides nutrients for microbial growth. Contains indigenous } \\
\text { microflora and promotes the development of Protozoa. }\end{array}$ \\
\hline 9 & Dried weed stems & $\begin{array}{l}\text { Natural } \\
\text { organic }\end{array}$ & $\begin{array}{l}\text { Provides nutrients for microbial growth. Contains indigenous } \\
\text { microflora and promotes the development of Protozoa. }\end{array}$ \\
\hline 10 & Wood shavings & $\begin{array}{l}\text { Natural } \\
\text { organic }\end{array}$ & $\begin{array}{l}\text { Resistant to microbial degradation. Good washability. The } \\
\text { rigid structure prevents sticking. Smaller fouling surface area } \\
\text { compared to other carriers. }\end{array}$ \\
\hline
\end{tabular}

The concentration of the soluble organic compounds (CSOC) was determined in terms of total carbon concentration using the permanganate method [28]. The potentiometric measurements of $\mathrm{pH}$ and Eh were performed with an EZDO MP-103 handheld $\mathrm{pH}$ meter (Gondo Electronic, Taipei, Nangang District, Taiwan) outfitted with a combined ceramic PY41 silver chloride electrode, PO50 ORP electrode, and a temperature sensor [29]. The amount of gas in gasholders and its composition were determined by standard methods [30].

The optical density of the culture fluid was determined with a photoelectrocolorimeter KFK-2MP (JSC «Zagorsk optical and mechanical plant», Sergiev Posad, Russia) at $540 \mathrm{~nm}$ in a cuvette with an optical path of $3 \mathrm{~mm}$ [31]. Microscopic observations of bacteria in biofilms and culture fluid were performed with a LOMO Mikmed-2 compound microscope using the wet mount technique [32]. The invertebrates and Protozoa were observed using the hanging drop mount at $\times 20$ magnification [33]. The quantitation of live microorganisms was performed by dilution plating of culture fluid on full-strength (copeotrophic conditions) or 0.1-strength (oligotrophic conditions) glucose-potato agar (GPA) [34]. The inoculated plates were incubated for 14 days at $27^{\circ} \mathrm{C}$ [25,35]. All samples were plated in triplicate $(n=3)$ and compared by calculating mean values (x) and standard deviations (SD). 


\section{Results}

\subsection{Hydrogen Fermentation of the Multicomponent Food Waste}

The initial no-flow inoculation of hydrogen bioreactor with the GMP1 granular microbial preparation resulted in a sharp decrease of redox potential from $+344 \pm 35 \mathrm{mV}$ to $-74 \pm 8.2 \mathrm{mV}$ within $12 \mathrm{~h}$ (Figure $4 \mathrm{a}$ ). The oxygen depletion in the gas phase by facultative anaerobic microorganisms and stabilization of anaerobic conditions led to the onset of hydrogen synthesis. These changes were accompanied by a sharp drop in $\mathrm{pH}$ from $7.2 \pm 0.4$ to $5.6 \pm 0.3$ that occurred between 12 to $20 \mathrm{~h}$ due to the active hydrolysis of polymers. To neutralize the inhibitory effect of this acidification on the production of hydrogen, the medium was amended by proprietary regulators of microbial metabolism. The hydrolysis of organic solids and hydrogen output stabilized between 22 and $40 \mathrm{~h}$ of cultivation. This was accompanied by a slight drop in $\mathrm{pH}$ from $6.4 \pm 0.32$ to $6.2 \pm 0.3$, the redox potential ranging between $-265 \pm 30$ and $-234 \pm 25.5 \mathrm{mV}$, and hydrogen concentration of $44.1 \pm 4.5 \%$ in the 40 th hour of cultivation (Figure $4 \mathrm{a}$ ).
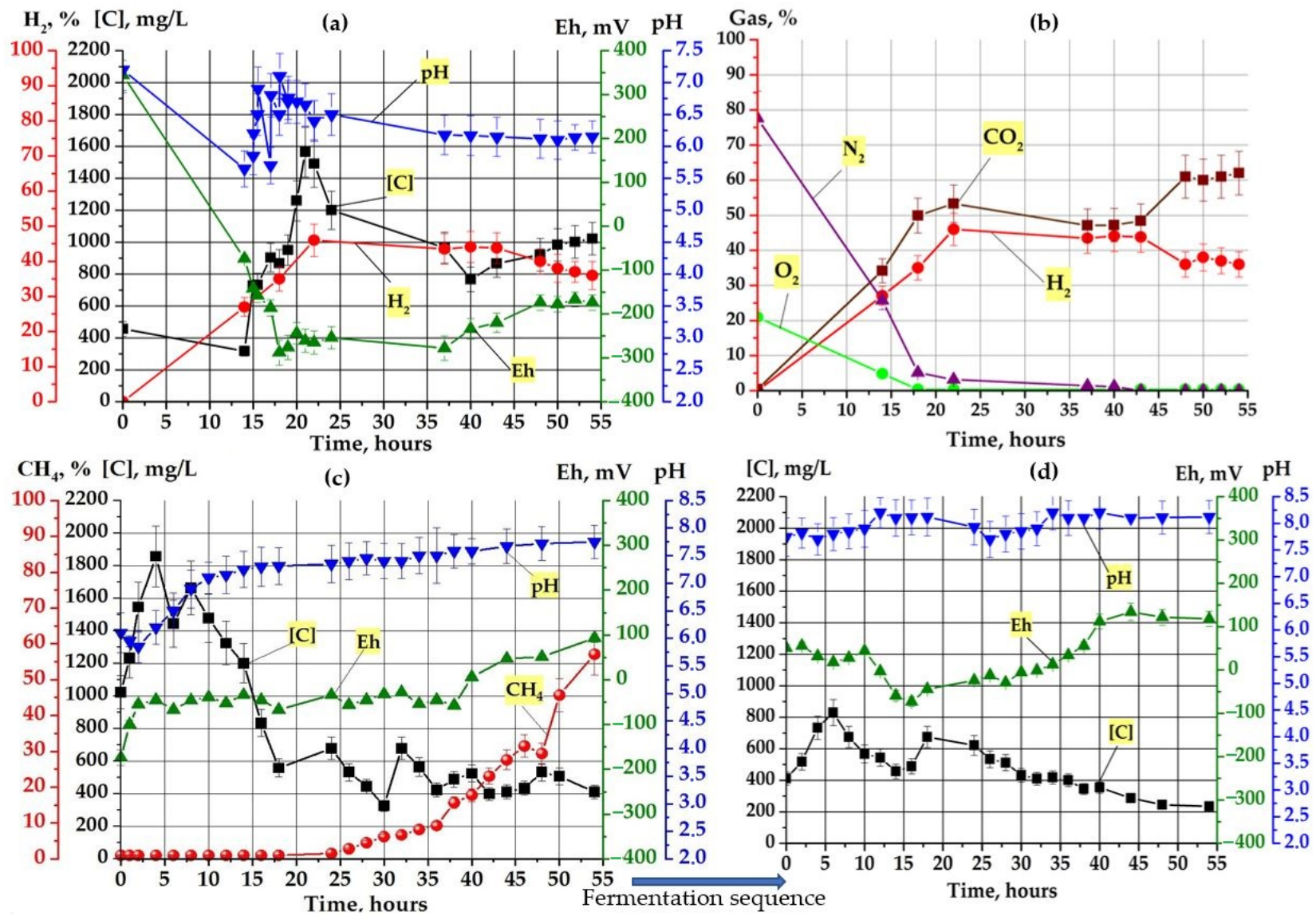

Figure 4. The dynamics of metabolic parameters and gas composition during the fermentation of multicomponent food waste in the hydrogen bioreactor $(\mathbf{a}, \mathbf{b})$ and subsequent anaerobic degradation of fatty acids and alcohols in the two-module methane tank (c,d). The concentration of $\mathrm{H}_{2}$ and $\mathrm{CH}_{4}$ is shown by red lines. Green lines represent the redox potential, while the total carbon concentration is shown in black. The blue and green lines correspond to $\mathrm{pH}$ and $\mathrm{O}_{2}$ concentration, while fluctuations in levels of $\mathrm{N}_{2}$ and $\mathrm{CO}_{2}$ are shown in brown and purple colors, respectively. Data points and error bars represent mean values $(n=3)$ and standard deviations.

The effective degradation of solid food waste was evidenced by a visual decrease in the volume of food waste and a sharp increase in the concentration of soluble organic compounds, which increased from $318 \pm 15.9$ to $1564 \pm 78.2 \mathrm{mg} / \mathrm{L}$ between 12 and $21 \mathrm{~h}$ of fermentation. At the same time, the concentration of soluble compounds decreased from 
$1564 \pm 78.2 \mathrm{mg} / \mathrm{L}$ to $1022 \pm 56.1 \mathrm{mg} / \mathrm{L}$. The entire fermentation process took only $54 \mathrm{~h}$, during which the weight of solid food waste dropped by 55 -fold. This was accompanied by the high hydrogen yield of $73 \mathrm{~L} / \mathrm{kg}$ of total solids and a maximum $\mathrm{H}_{2}$ concentration of $46.0 \pm 5.1 \%$. The biohydrogen was captured in the gasholder and further purified, resulting in the final concentration of 95\% (Figure 1a8). The hydrogen bioreactor leachate was continuously transferred into the methane tank at a rate of $0.5 \mathrm{~L} / \mathrm{h}$.

\subsection{The Purification of Hydrogen Bioractor Leachate with Methane Fermentation}

The study revealed highly efficient purification of the hydrogen tank leachate by the methanogenic granular microbial preparation GMP2. After the hydrogen fermentation of food waste, the total organic carbon concentration in the cell-free leachate was $1022 \pm 56.1 \mathrm{mg} / \mathrm{L}$. In addition to soluble organic compounds, the leachate also contained a high concentration of anaerobic microorganisms. Within four hours of incubation in the methane tank, the concentration of soluble organics sharply increased from $1022 \pm 56.1 \mathrm{mg} / \mathrm{L}$ to $1857 \pm 123 \mathrm{mg} / \mathrm{L}$, probably due to the hydrolysis of the biomass of hydrogen-synthesizing microorganisms (Figure 4c). Later, the total soluble carbon quickly dropped to $411 \pm 45.6 \mathrm{mg} / \mathrm{L}$ and $234 \pm 31.2 \mathrm{mg} / \mathrm{L}$ in the first and second methane tank sections, respectively. A concomitant increase in $\mathrm{pH}$ from $6.1 \pm 0.4$ to $7.7 \pm 0.3$ suggested an accumulation of $\mathrm{NH}_{4}{ }^{+}$due to the breakdown of protein compounds from the biomass of anaerobes.

The redox potential increased from $-100 \pm 12 \mathrm{mV}$ to $93 \pm 14.5 \mathrm{mV}$, which is out of the range optimal for the induction of methanogenesis $(-300--350 \mathrm{mV})$. It is likely that under these conditions, the methanogenic fermentation was limited to the sediment at the bottom of the methane tanks. A total of $87 \mathrm{~L}$ of gas was produced during the anaerobic leachate purification, including $42 \mathrm{~L}$ of methane $\left(\mathrm{CH}_{4}\right)$ and $45 \mathrm{~L}$ of carbon dioxide $\left(\mathrm{CO}_{2}\right)$. In other words, the filtrate purification via methanogenic fermentation of volatile

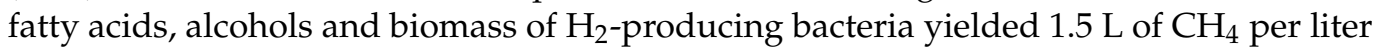
of leachate. The significant production of biomethane started at $24 \mathrm{~h}$ and steadily rose, reaching $57.1 \pm 6.3 \%$ at the end of the experiment $(54 \mathrm{~h}$ ) (Figure $4 \mathrm{c}$ ). However, the gradual increase of Eh signaled that the fermentation process was approaching completion. The captured biomethane was separated from impurities and had a final concentration of $95 \%$. Collectively, these results demonstrate the feasibility of recruiting anaerobic microbial processes to purify hydrogen fermentation leachates and generate methane during the recycling of solid multi-component organic waste.

\subsection{The Purification of Methane Fermentation Leachate Using Air Tank Technology}

The leachate formed during the methane fermentation was purified in a multi-section air tank harboring a spatial succession of communities of aerobic bacteria, Protozoa, invertebrates (rotifers, nematodes), and insect larvae (Figure 5). Despite aeration, the transfer of the methane tank leachate ( $\mathrm{pH} 7.7 \pm 0.3)$ containing methanogens and reducing compounds created anaerobic conditions in the first four sections of the air tank. Hence, the consumption of the methanogenic biomass by copeotrophic bacteria in this part of the air tank involved primarily anaerobic processes. Interestingly, the redox potential of leachate measured in the second methane tank was higher than in the front air tank section (Figure 5).

We attribute this discrepancy to the fact that samples from the second methane tank included culture liquid with a potential of $+105 \pm 12 \mathrm{mV}$ and sludge containing high levels of metabolically active methanogens. In addition, this microbial suspension was pumped into the air tank from the bottom of the methane tank. Therefore, the Eh of leachate in the first air tank sections was $-380 \pm 38 \mathrm{mV}$ due to the presence of the low-potential obligate anaerobic microorganisms. As the leachate flowed through the front part of the air tank, the redox potential gradually rose to $+60 \pm 6 \mathrm{mV}$ due to protein deamination associated with the degradation of methanogen biomass. These processes also decreased the concentration 
of soluble organic compounds from $234 \pm 31.2 \mathrm{mg} / \mathrm{L}$ in the first section to $110 \pm 21.5 \mathrm{mg} / \mathrm{L}$ in the fourth section and, finally, to $40 \pm 3.2 \mathrm{mg} / \mathrm{L}$ in section 10.
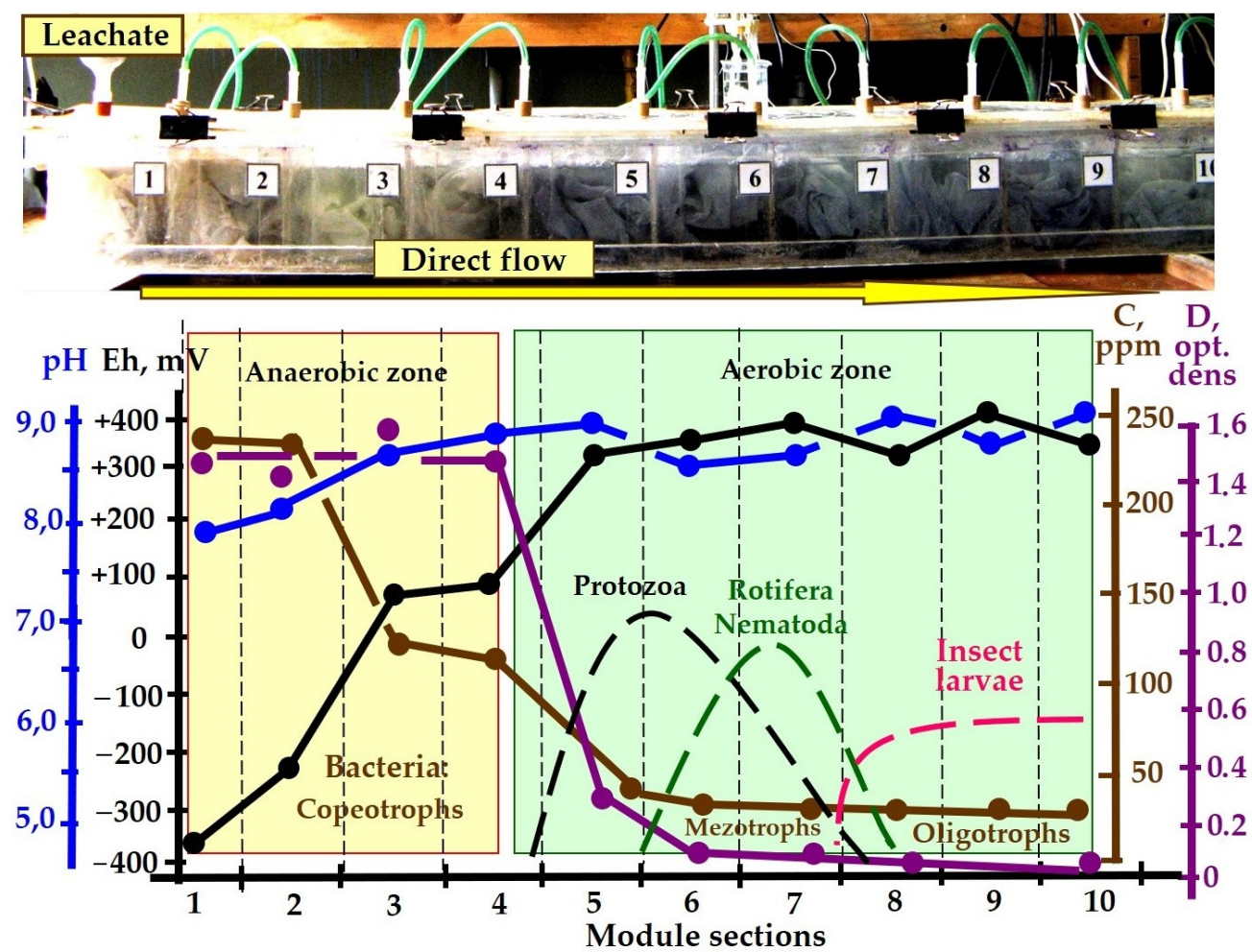

Figure 5. The overview of the air tank and variation in the levels of $\mathrm{pH}$, Eh, total organic carbon, and optical density (540 nm) across individual sections harboring spatially separated communities of aerobic bacteria, Protozoa, invertebrates (rotifera, nematodes), and insect larvae.

The degradation of the methanogen biomass and significant decrease in the concentration of soluble organic compounds resulted in the establishment of aerobic conditions in the air tank sections 5 through 10. As a result, the redox potential in Section 5 increased to $+300 \pm 25 \mathrm{mV}$ and remained between $+350 \pm 25$ and $+400 \pm 43 \mathrm{mV}$ in the rest of the sections (Figure 5).

The decrease in the level of organic compounds led to the establishment of a succession of microorganisms across the air tank length, where copeotrophs dominating the front part were replaced in more distant sections by mesotrophs and oligotrophs. The aerobic conditions also resulted in the growth and proliferation of other micro- and macroorganisms in sections 5-10. The abundance of bacteria created optimal conditions for the development of Protozoa, which served as a nutrient source for rotifers and nematodes that proliferated in sections 5 and 6 . These invertebrates almost completely disappeared from sections 8 to 10, where they served as a food source for insect larvae. Thus, the air tank supported several spatially separated communities that collectively cleaned the water from residual fatty acids, alcohols, and bacterial contamination.

\subsection{Aquarium as the Final Stage of the Leachate Purification}

The final stage of the purification took place in an aquarium that housed planktonic and benthic microorganisms, microalgae, duckweed, stream algae, Protozoa, insect larvae, and fish. This module represented a closed nutrient cycle and did not require additional carbon and energy sources. The aquarium ecosystem was supported by the residual nutrients, Rotifera and Nematoda, in the air tank outflow. Insect larvae from the air tank served as a food source for fish (Figure 6b). Additional carbon and energy were provided by primary producers that included photosynthetic microalgae and duckweed. 

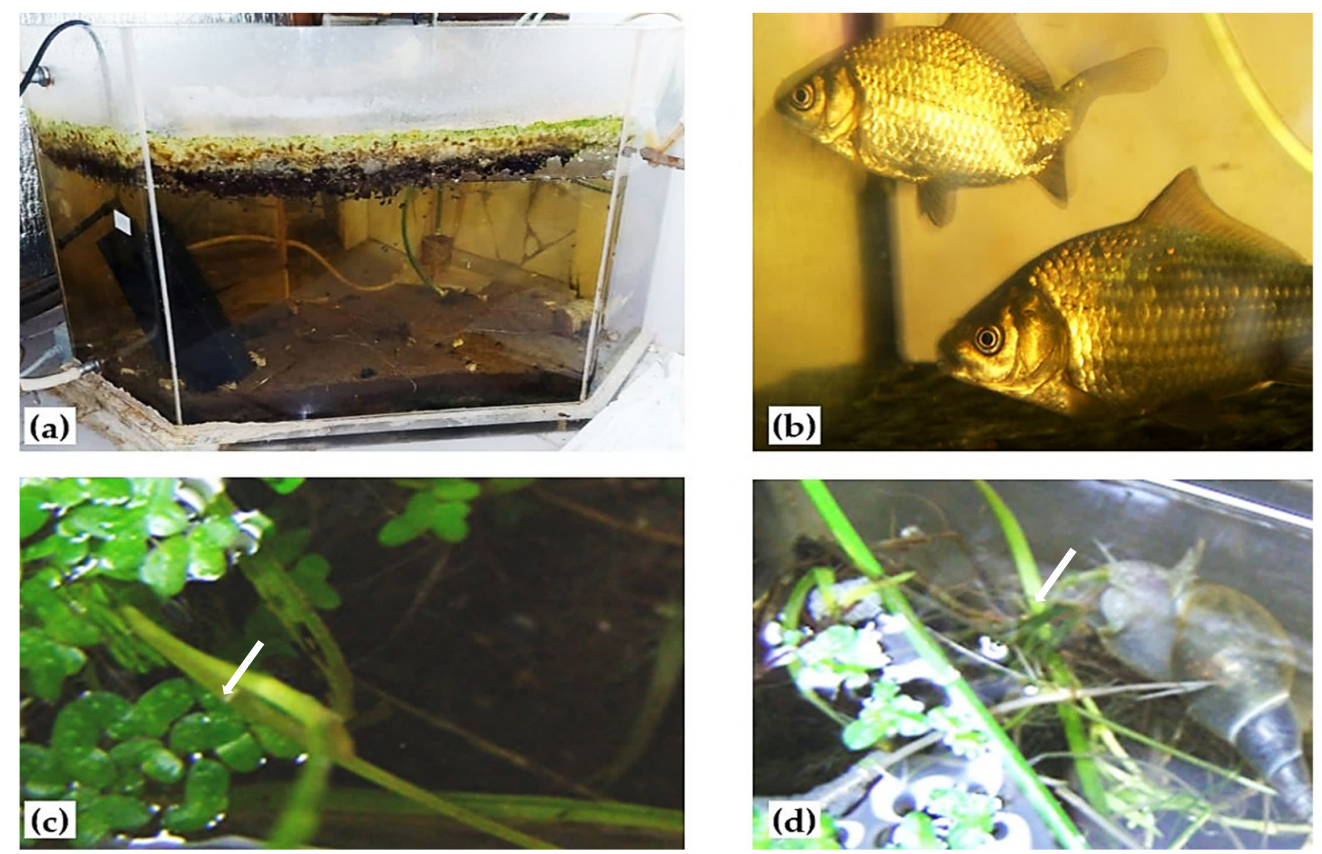

Figure 6. The general appearance of the aquarium module (a) and its inhabitants, such as crucian carp (Carassius carassius) (b), Tubifex worms (c), and snail (d).

The content of organic compounds in this final module was low and did not exceed $3.0 \pm 0.5 \mathrm{mg} / \mathrm{L}$ of total carbon. The aquarium ecosystem acted as the final purification stage and generated water that met the "environmentally safe" standard. In summary, the four-module flow installation housing a succession of anaerobic and aerobic microbial communities, Protozoa, invertebrates, insect larvae, and fish degraded the multicomponent food waste, generated energy carriers $\mathrm{H}_{2}$ and $\mathrm{CH}_{4}$, and produced ecologically safe water by purifying the leachate from organic compounds.

\section{Discussion}

This study presents a technology that combines aerobic and anaerobic microorganisms, algae, protozoa, aquatic micro- and macroinvertebrates, and fish to recycle multicomponent food waste and generate gaseous energy carriers. This approach has several advantages over the more traditional use of landfills, where buried food waste undergoes spontaneous fermentation with low methane yields [36]. The use of landfills also leads to the accumulation of toxic leachates containing highly concentrated (thousands and tens of thousands of milligrams per liter in terms of total carbon content) volatile fatty acids (VFAs) and alcohols [13]. When compared to conventional landfill dumping, our technology offers several crucial benefits, including (1) the rapid breakdown of solid and liquid organic waste, (2) the cleanup of associated toxic leachates, (3) the generation of residue that can be used as a solid fuel (lignocellulose from unfermented plant polymers), and (4) the efficient synthesis of energy in the form of $\mathrm{H}_{2}$ and $\mathrm{CH}_{4}$.

The concept of combining waste recycling with the production of green energy requires tight coupling of (1) anaerobic hydrolysis of polymers with the formation of $\mathrm{H}_{2}, \mathrm{CO}_{2}, \mathrm{VFAs}$, and alcohols, (2) anaerobic degradation of soluble $\mathrm{C}_{2}-\mathrm{C}_{6}$ VFAs and alcohols to onecarbon compounds, (3) accumulation of methanogenesis precursors $\left(\mathrm{H}_{2}, \mathrm{CO}_{2}\right.$, formate, methanol, methylamine), and (4) synthesis of methane from $\mathrm{H}_{2}, \mathrm{CO}_{2}$ and one-carbon fatty acids and alcohols. Balancing these processes in landfills or conventional anaerobic reactors is challenging and often leads to disrupting syntrophic interactions and poor biogas yields [37,38]. For example, one study cited the highest biohydrogen yield of only $46 \mathrm{~L} / \mathrm{kg}$ after co-fermentation of garden and food waste [39]. In another study, the thermophilic anaerobic co-digestion of the organic fractions of solid municipal and food wastes resulted in the $\mathrm{H}_{2}$ yield of $38 \mathrm{~L} / \mathrm{kg}$ of $\mathrm{VS}_{\text {added }}[40]$. 
We solved these issues by using a direct-flow installation, which spatially separates syntrophic microbial communities that break down mixed organic waste and generate hydrogen or methane energy. In conventional biogas technology, the mixing of solid waste results in the accumulation of toxic exometabolites that inhibit the process of fermentation. In contrast, our direct-flow design helps to significantly decrease the concentration of inhibitory metabolites on the surface of solid waste in the anaerobic bioreactor. Another crucial aspect of our experimental and theoretical approach was the use of microbial inocula to ensure the efficient function of the spatial succession of microbial communities. In addition, the use of proprietary regulators of microbial metabolism helped maintain optimal conditions for the growth of hydrogen- and methane-synthesizing microorganisms. Finally, in contrast to numerous model studies using glucose [41], starch [42], hexose, or glycerin [43], our experiments involved a mixed substrate that closely resembled the composition of organic municipal waste. The waste degradation coefficient in our study was high $(K d=55)$, testifying to the high efficiency of the process and the possibility of industrial scaling [20,44-46].

It has been estimated that municipal food waste contains on average $30-60 \%$ carbohydrates, $5-25 \%$ fats, $5-20 \%$ proteins, and $1-10 \%$ inorganic compounds $[44,47,48]$. The heterogeneous nature of such substrates makes it difficult to achieve stable and predictable energy output, and current food waste-based biohydrogen production technologies can generate only $30 \%$ of the potential energy yield [20]. Despite the drawbacks, food waste represents a cheap, constantly renewable substrate that holds promise for the industrial production of biogas. The yield of biohydrogen and biomethane in our study was $73 \mathrm{~L} / \mathrm{k}$ and $42 \mathrm{~L} / \mathrm{kg}$ of total solids, thus supporting this notion. It should be noted that the amounts of methane generated in our system were lower compared to those achieved by fermenting banana peels with cattle dung (219-231 $\mathrm{L} \mathrm{CH}_{4} / \mathrm{kg} \mathrm{TS}_{\text {added }}$ ) [49] or $\mathrm{NaOH}-$ pretreated wheat straw (165.9 $\mathrm{L} \mathrm{CH}_{4} / \mathrm{kg} \mathrm{VS}_{\mathrm{a}}$ ) [50]. However, these results are difficult to compare directly because, in our system, the methane was generated using the liquid by-product of hydrogen fermentation, which does not contain energy-dense carbohydrates.

Among the goals of this work was to achieve high $\mathrm{H}_{2}$ and $\mathrm{CH}_{4}$ yields and significantly decrease the concentration of organic compounds in fermentation leachates. The process of burying organic wastes in landfills results in the accumulation of liquid leachates, whose toxicity has been documented in numerous studies [51-53]. The treatment of landfill leachates is a global problem since none of the existing physical, chemical or biological technologies are capable of dealing with this widespread issue effectively $[51,52,54]$. Moderately-concentrated leachates can be treated with $\mathrm{FeSO}_{4} \times 7 \mathrm{H}_{2} \mathrm{O}$ and $\mathrm{FeCl}_{3} \times 6 \mathrm{H}_{2} \mathrm{O}$, which decreases the total organic carbon by 37\% [55]. Slightly better results were achieved with potassium ferrate(VI) $\left(\mathrm{K}_{2} \mathrm{FeO}_{4}\right)$, which reduced the concentration of total organic compounds by $82.6 \%$ [55]. However, the leachates containing very high levels (thousands and tens of thousands $\mathrm{mg} / \mathrm{L}$ ) of organic compounds require several purification steps, making the process economically unprofitable. In addition, the use of treatment agents containing heavy metals, especially $\mathrm{Fe}(\mathrm{II})$, can lead to the spontaneous growth of obligate anaerobes that synthesize $\mathrm{H}_{2} \mathrm{~S}, \mathrm{CH}_{4}$, mercaptans, and other harmful substances. An alternative way of detoxifying leachates relies on various physicochemical technologies [56]. For example, the treatment with reverse osmosis resulted in up to $99-99.5 \%$ reduction in chemical oxygen demand (COD) [57]. A combination of electrocoagulation and anaerobic treatment reduced COD in liquid organic waste by $92 \%$ [58]. Among the disadvantages of physicochemical technologies are their high cost and/or the need for biological pre-treatment steps to achieve maximum efficiency [59].

In our study, the initial concentration of organic compounds in the hydrogen fermentation leachate was $1022 \pm 56.1 \mathrm{mg} / \mathrm{L}$ and further increased to $1857 \pm 123 \mathrm{mg} / \mathrm{L}$ after four hours of polymer hydrolysis by methanogens. However, in the final installation module (i.e., aquarium), the levels of organic compounds did not exceed $3.0 \pm 0.5 \mathrm{mg} / \mathrm{L}$. This amounts to the purification efficiency of $99.8 \%$, which matches or exceeds values reported in other relevant studies [56-58,60]. Finally, our cleanup technology relies solely on biologi- 
cal processes and does not require chemicals or physicochemical methods, significantly reducing operating costs.

\section{Conclusions}

Various combinations of microbiological, physical, and physicochemical approaches have been used for decades to treat sewage and industrial wastewater. Recently, there have been attempts to further advance this field by coupling microbial cleanup technologies with energy production. The four-module direct-flow installation used in this study efficiently couples anaerobic and aerobic bacteria with other micro- and macroorganisms to simultaneously recycle organic waste, remediate the resulting leachate, and generate biogas. Such approaches can help meet the growing worldwide demands in clean, fresh water and sustainable energy.

Author Contributions: Investigation, O.T., V.H., O.H., O.K., G.G.; Conceptualization, O.T., P.W.; Resources, V.H., O.K., O.T, I.S., P.W., D.S., G.G.; Software, O.K.; Methodology, O.T., O.K., I.S., P.W., H.Z, Y.I.; Supervision, O.T., V.H.; Writing-original draft preparation, V.H., O.H., O.T, O.K., P.W., D.S., I.S., G.G., H.Z., Y.I.; Writing-reviewing \& editing, V.H., O.K. All authors have read and agreed to the published version of the manuscript.

Funding: This research was funded in part by the Comprehensive Program of Basic Research of the NAS of Ukraine "Fundamental problems of hydrogen and renewable energy and fuel cell technologies" [grant \# 2-18].

Institutional Review Board Statement: Not applicable.

Informed Consent Statement: Not applicable.

Data Availability Statement: Not applicable.

Acknowledgments: The authors are grateful to Dmitri Mavrodi of The University of Southern Mississippi for editing the manuscript.

Conflicts of Interest: The authors declare no conflict of interest.

\section{References}

1. Stovpets, O. Social-Ecological Approach to Analysis of the Municipal Waste Utilization Problem in Metropolis (through the Lens of Philosophy and Law). Skhid 2021, 165, 64-71. [CrossRef]

2. Schanes, K.; Dobernig, K.; Gözet, B. Food Waste Matters-A Systematic Review of Household Food Waste Practices and Their Policy Implications. J. Clean. Prod. 2018, 182, 978-991. [CrossRef]

3. Lu, H.R.; Qu, X.; Hanandeh, A.E. Towards a Better Environment-The Municipal Organic Waste Management in Brisbane: Environmental Life Cycle and Cost Perspective. J. Clean. Prod. 2020, 258, 120756. [CrossRef]

4. Das, S.; Lee, S.-H.; Kumar, P.; Kim, K.-H.; Lee, S.S.; Bhattacharya, S.S. Solid Waste Management: Scope and the Challenge of Sustainability. J. Clean. Prod. 2019, 228, 658-678. [CrossRef]

5. Reznikova, N.; Zvarych, R.; Zvarych, I.; Shnyrkov, O. Global Circular E-Chain in Overcoming the Global Waste. Procedia Environ. Sci. Eng. Manag. 2019, 6, 641-647.

6. Blair, J.; Mataraarachchi, S. A Review of Landfills, Waste and the Nearly Forgotten Nexus with Climate Change. Environments 2021, 8, 73. [CrossRef]

7. Stupnikova, Y.; Popova, K. Solution of Environmental Problems in Human Settlements Caused by Negative Effect of SDW Landfills. MATEC Web Conf. 2018, 193, 02006. [CrossRef]

8. Vaccari, M.; Tudor, T.; Vinti, G. Characteristics of Leachate from Landfills and Dumpsites in Asia, Africa and Latin America: An Overview. Waste Manag. 2019, 95, 416-431. [CrossRef]

9. Njoku, P.O.; Odiyo, J.O.; Durowoju, O.S.; Edokpayi, J.N. A Review of Landfill Gas Generation and Utilisation in Africa. Open Environ. Sci. 2018, 10, 1-15. [CrossRef]

10. Zhang, S.; Long, Y.; Fang, Y.; Du, Y.; Liu, W.; Shen, D. Effects of Aeration and Leachate Recirculation on Methyl Mercaptan Emissions from Landfill. Waste Manag. 2017, 68, 337-343. [CrossRef]

11. Begum, S.; Arelli, V.; Anupoju, G.R.; Sridhar, S.; Bhargava, S.K.; Eshtiaghi, N. Optimization of Feed and Extractant Concentration for the Liquid-Liquid Extraction of Volatile Fatty Acids from Synthetic Solution and Landfill Leachate. J. Ind. Eng. Chem. 2020, 90, 190-202. [CrossRef]

12. Ou, J.; Xu, N.; Ernst, P.; Ma, C.; Bush, M.; Goh, K.; Zhao, J.; Zhou, L.; Yang, S.-T.; Liu, X. (Margaret) Process Engineering of Cellulosic N-Butanol Production from Corn-Based Biomass Using Clostridium Cellulovorans. Process Biochem. 2017, 62, 144-150. [CrossRef] 
13. Yan, C.-T.; Jen, J.-F. Determination of Volatile Fatty Acids in Landfill Leachates by Gas Chromatography with Distillation Pretreatment. Anal. Chim. Acta 1992, 264, 259-264. [CrossRef]

14. Yebouet, O.F.; Campitelli, A.; Amoikon, S.L.T.; Kannengiesser, J.; Stanojkovski, D.; Mrukwia, T.; Dje Koffi, M.; Djeni, T.N. Assessment of the Diversity and Abundance of Bacterial Population and Its Correlation with Medium Chain Fatty Acids Production from Fermentation of Two Leachate Qualities. Bioresour. Technol. Rep. 2021, 16, 100840. [CrossRef]

15. Wang, Y.; Zhang, Y.; Wang, J.; Meng, L. Effects of Volatile Fatty Acid Concentrations on Methane Yield and Methanogenic Bacteria. Biomass Bioenergy 2009, 33, 848-853. [CrossRef]

16. Salsali, H.; Parker, W.J.; Sattar, S.A. The Effect of Volatile Fatty Acids on the Inactivation of Clostridium Perfringens in Anaerobic Digestion. World J. Microbiol. Biotechnol. 2008, 24, 659-665. [CrossRef]

17. Abiriga, D.; Vestgarden, L.S.; Klempe, H. Groundwater Contamination from a Municipal Landfill: Effect of Age, Landfill Closure, and Season on Groundwater Chemistry. Sci. Total Environ. 2020, 737, 140307. [CrossRef]

18. Pagliano, G.; Ventorino, V.; Panico, A.; Pepe, O. Integrated Systems for Biopolymers and Bioenergy Production from Organic Waste and By-Products: A Review of Microbial Processes. Biotechnol. Biofuels 2017, 10, 113. [CrossRef]

19. Saratale, G.D.; Chen, S.-D.; Lo, Y.-C.; Saratale, R.G.; Chang, J.-S. Outlook of Biohydrogen Production from Lignocellulosic Feedstock Using Dark Fermentation-a Review. J. Sci. Ind. Res. 2008, 67, 962-979. Available online: https: / www.researchgate.net/publication/ 242126677_Outlook_of_biohydrogen_production_from_lignocellulosic_feedstock_using_dark_fermentation_-_A_review (accessed on 10 November 2021).

20. Ghimire, A.; Frunzo, L.; Pirozzi, F.; Trably, E.; Escudie, R.; Lens, P.N.L.; Esposito, G. A Review on Dark Fermentative Biohydrogen Production from Organic Biomass: Process Parameters and Use of by-Products. Appl. Energy 2015, 144, 73-95. [CrossRef]

21. Sun, L.; Fujii, M.; Tasaki, T.; Dong, H.; Ohnishi, S. Improving Waste to Energy Rate by Promoting an Integrated Municipal Solid-Waste Management System. Resour. Conserv. Recycl. 2018, 136, 289-296. [CrossRef]

22. Khayum, N.; Anbarasu, S.; Murugan, S. Biogas Potential from Spent Tea Waste: A Laboratory Scale Investigation of Co-Digestion with Cow Manure. Energy 2018, 165, 760-768. [CrossRef]

23. Ananthu, O.S. Small Scale Biogas Production by Using Food Waste-Examples from Three Restaurants. Master's Thesis, School of Business, Engineering and Science, Halmstad University, Halmstad, Sweden, 29 April 2019. Available online: https: / / www.divaportal.org/smash/record.jsf?pid=diva2:1307859 (accessed on 11 November 2021).

24. Tashyrev, O.B.; Matvieieva, N.A.; Hovorukha, V.M.; Tashyreva, H.O.; Bielikova, O.I.; Havryliuk, O.A.; Duplij, V.P. Application of Lignocellulosic Substrate Obtained after Hydrogen Dark Fermentation of Food Waste as Biofertilizer. Ind. Biotechnol. 2018, 14, 315-322. [CrossRef]

25. Hovorukha, V.; Havryliuk, O.; Gladka, G.; Tashyrev, O.; Kalinichenko, A.; Sporek, M.; Dołhańczuk-Śródka, A. Hydrogen Dark Fermentation for Degradation of Solid and Liquid Food Waste. Energies 2021, 14, 1831. [CrossRef]

26. Havryliuk, O.; Hovorukha, V.; Savitsky, O.; Trilis, V.; Kalinichenko, A.; Dołhańczuk-Śródka, A.; Janecki, D.; Tashyrev, O. Anaerobic Degradation of Environmentally Hazardous Aquatic Plant Pistia Stratiotes and Soluble Cu(II) Detoxification by Methanogenic Granular Microbial Preparation. Energies 2021, 14, 3849. [CrossRef]

27. Ivanov, Y.; Pyatnichko, O.; Zhuk, H.; Onopa, L.; Soltanibereshne, M. Extraction of Carbon Dioxide from Gas Mixtures with Amines Absorbing Process. Energy Proc. 2017, 128, 240-247. [CrossRef]

28. Suslova, O.; Govorukha, V.; Brovarskaya, O.; Matveeva, N.; Tashyreva, H.; Tashyrev, O. Method for Determining Organic Compound Concentration in Biological Systems by Permanganate Redox Titration. Int. J. Bioautom. 2014, 18, 45-52. Available online: https: / / www.proquest.com/openview /b5a0cc3a4fa9b603e25343417abc104e/1?pq-origsite=gscholar\&cbl=4720765 (accessed on 15 November 2021).

29. Hovorukha, V.; Havryliuk, O.; Tashyreva, H.; Tashyrev, O.; Sioma, I. Thermodynamic Substantiation of Integral Mechanisms of Microbial Interaction with Metals. Ecol. Eng. Environ. Prot. 2018, 2018, 55-63. [CrossRef]

30. Berezkin, V.G.; Drugov, Y.S. Gas Chromatography in Air Pollution Analysis; Elsevier: Amsterdam, The Netherlands, 1991; ISBN 978-0-08-085856-2.

31. Begot, C.; Desnier, I.; Daudin, J.D.; Labadie, J.C.; Lebert, A. Recommendations for Calculating Growth Parameters by Optical Density Measurements. J. Microbiol. Methods 1996, 25, 225-232. [CrossRef]

32. Levin, P.A. 6 Light Microscopy Techniques for Bacterial Cell Biology. In Methods in Microbiology; Academic Press: Cambridge, MA, USA, 2002; Volume 31, pp. 115-132. ISBN 0580-9517.

33. Bakht, A.; Rasool, N.; Iftikhar, S. Characterization of Plastic Degrading Bacteria Isolated from Landfill Sites. J. Biochem. Microbiol. Technol. Eng. 2020, 3, 030-035. [CrossRef]

34. Taylor, J. The Estimation of Numbers of Bacteria by Tenfold Dilution Series. J. Appl. Bacteriol. 1962, 25, 54-61. [CrossRef]

35. Tashyrev, O. Natural and Synthetic Solid Carriers in Flow Module For Microbial Sewage Filtrate Purification. Biotechnol. Acta 2018, 11, 73-81. [CrossRef]

36. Zhan, L.-T.; Xu, H.; Chen, Y.-M.; Lü, F.; Lan, J.-W.; Shao, L.-M.; Lin, W.-A.; He, P.-J. Biochemical, Hydrological and Mechanical Behaviors of High Food Waste Content MSW Landfill: Preliminary Findings from a Large-Scale Experiment. Waste Manag. 2017, 63, 27-40. [CrossRef] [PubMed]

37. Enzmann, F.; Mayer, F.; Rother, M.; Holtmann, D. Methanogens: Biochemical Background and Biotechnological Applications. $A M B$ Express 2018, 8, 1. [CrossRef] 
38. Demirel, B.; Scherer, P. The Roles of Acetotrophic and Hydrogenotrophic Methanogens during Anaerobic Conversion of Biomass to Methane: A Review. Rev. Environ. Sci. Biotechnol. 2008, 7, 173-190. [CrossRef]

39. Abreu, A.; Tavares, F.; Alves, M.; Cavaleiro, A.J.; Pereira, M.A. Garden and Food Waste Co-Fermentation for Biohydrogen and Biomethane Production in a Two-Step Hyperthermophilic-Mesophilic Process. Bioresour. Technol. 2019, 278, 180-186. [CrossRef] [PubMed]

40. Angeriz-Campoy, R.; Álvarez-Gallego, C.J.; Romero-García, L.I. Thermophilic Anaerobic Co-Digestion of Organic Fraction of Municipal Solid Waste (OFMSW) with Food Waste (FW): Enhancement of Bio-Hydrogen Production. Bioresour. Technol. 2015, 194, 291-296. [CrossRef]

41. Anburajan, P.; Park, J.-H.; Pugazhendhi, A.; Kim, J.-S.; Kim, S.-H. Biohydrogen Production from Glucose Using Submerged Dynamic Filtration Module: Metabolic Product Distribution and Flux-Based Analysis. Bioresour. Technol. 2019, $287,121445$. [CrossRef]

42. Wang, S.; Ma, Z.; Zhang, T.; Bao, M.; Su, H. Optimization and Modeling of Biohydrogen Production by Mixed Bacterial Cultures from Raw Cassava Starch. Front. Chem. Sci. Eng. 2017, 11, 100-106. [CrossRef]

43. de Sá, L.R.V.; Cammarota, M.C.; de Oliveira, T.C.; Oliveira, E.M.M.; Matos, A.; Ferreira-Leitão, V.S. Pentoses, Hexoses and Glycerin as Substrates for Biohydrogen Production: An Approach for Brazilian Biofuel Integration. Int. J. Hydrog. Energy 2013, 38, 2986-2997. [CrossRef]

44. Paritosh, K.; Kushwaha, S.K.; Yadav, M.; Pareek, N.; Chawade, A.; Vivekanand, V. Food Waste to Energy: An Overview of Sustainable Approaches for Food Waste Management and Nutrient Recycling. BioMed Res. Int. 2017, 2017, 2370927. [CrossRef] [PubMed]

45. Zhang, M.-L.; Fan, Y.-T.; Xing, Y.; Pan, C.-M.; Zhang, G.-S.; Lay, J.-J. Enhanced Biohydrogen Production from Cornstalk Wastes with Acidification Pretreatment by Mixed Anaerobic Cultures. Biomass Bioenergy 2007, 31, 250-254. [CrossRef]

46. Hawkes, F.R.; Hussy, I.; Kyazze, G.; Dinsdale, R.; Hawkes, D.L. Continuous Dark Fermentative Hydrogen Production by Mesophilic Microflora: Principles and Progress. Int. J. Hydrog. Energy 2007, 32, 172-184. [CrossRef]

47. Yasin, N.H.M.; Mumtaz, T.; Hassan, M.A.; Abd Rahman, N. Food Waste and Food Processing Waste for Biohydrogen Production: A Review. J. Environ. Manag. 2013, 130, 375-385. [CrossRef]

48. Curry, N.; Pillay, P. Biogas Prediction and Design of a Food Waste to Energy System for the Urban Environment. Renew Energy 2012, 41, 200-209. [CrossRef]

49. Bardiya, N.; Somayaji, D.; Khanna, S. Biomethanation of Banana Peel and Pineapple Waste. Bioresour. Technol. 1996, 58, 73-76. [CrossRef]

50. Chandra, R.; Takeuchi, H.; Hasegawa, T.; Kumar, R. Improving Biodegradability and Biogas Production of Wheat Straw Substrates Using Sodium Hydroxide and Hydrothermal Pretreatments. Energy 2012, 43, 273-282. [CrossRef]

51. Clément, B.; Merlin, G. The Contribution of Ammonia and Alkalinity to Landfill Leachate Toxicity to Duckweed. Sci. Total Environ. 1995, 170, 71-79. [CrossRef]

52. Baderna, D.; Caloni, F.; Benfenati, E. Investigating Landfill Leachate Toxicity in Vitro: A Review of Cell Models and Endpoints. Environ. Int. 2019, 122, 21-30. [CrossRef]

53. Chen, D.M.-C.; Bodirsky, B.L.; Krueger, T.; Mishra, A.; Popp, A. The World's Growing Municipal Solid Waste: Trends and Impacts. Environ. Res. Lett. 2020, 15, 074021. [CrossRef]

54. Wiszniowski, J.; Robert, D.; Surmacz-Gorska, J.; Miksch, K.; Weber, J.V. Landfill Leachate Treatment Methods: A Review. Environ. Chem. Lett. 2006, 4, 51-61. [CrossRef]

55. Thomas, M.; Kozik, V.; Barbusiński, K.; Sochanik, A.; Jampilek, J.; Bąk, A. Potassium Ferrate (VI) as the Multifunctional Agent in the Treatment of Landfill Leachate. Materials 2020, 13, 5017. [CrossRef] [PubMed]

56. Abuabdou, S.M.A.; Jaffari, Z.H.; Ng, C.-A.; Ho, Y.-C.; Bashir, M.J.K. A New Polyvinylidene Fluoride Membrane Synthesized by Integrating of Powdered Activated Carbon for Treatment of Stabilized Leachate. Water 2021, 13, 2282. [CrossRef]

57. Tałałaj, I.A.; Biedka, P.; Bartkowska, I. Treatment of Landfill Leachates with Biological Pretreatments and Reverse Osmosis. Environ. Chem. Lett. 2019, 17, 1177-1193. [CrossRef]

58. Tezcan Un, U.; Filik Iscen, C.; Oduncu, E.; Akcal Comoglu, B.; Ilhan, S. Treatment of Landfill Leachate Using Integrated Continuous Electrocoagulation and the Anaerobic Treatment Technique. Environ. Prog. Sustain. Energy 2018, 37, $1668-1676$. [CrossRef]

59. Yi, E.X.; Wee, S.T.; Lim, C.K.; Ibrahim, Z.; Chan, N.W. Combined Adsorption and Biological Treatment for Landfill Leachate Management. J. Adv. Res. Fluid Mech. Therm. Sci. 2018, 50, 26-31. [CrossRef]

60. Pashaki, S.G.A.; Khojastehpour, M.; Ebrahimi-Nik, M.; Rohani, A. Treatment of Municipal Landfill Leachate: Optimization of Organic Loading Rate in a Two-Stage CSTR Followed by Aerobic Degradation. Renew Energy 2021, 163, 1210-1221. [CrossRef] 